\title{
AKTIVITAS ANTIBAKTERI KITOSAN TERHADAP BAKTERI S.aureus
}

\author{
Mardiyah Kurniasih, Dwi Kartika \\ Program Studi Kimia, Jurusan MIPA
}

Fakultas Sains dan Teknik, Universitas Jenderal Soedirman, Purwokerto

\begin{abstract}
Chitosan is the N-deacetylated derivative of chitin. Chitosan is biodegradable, biocompatible and non-toxic. Chitosan is polycationic in acidic media and give antibacterial activity. In this paper, antibacterial activity of chitosan have been studied.

Chitosan had been isolated from white shrimp. Antibacterial activity of chitosan solutions was examined against $S$. aureus The result showed that antimicrobial effect on $S$. aureus was strengthened as the choitosan concentrate decreased.
\end{abstract}

Keywords: chitosan, antibacterial test, $S$. aureus

\section{PENDAHULUAN}

Kitosan yang tiap tahunnya dihasilkan 100 trilyun ton oleh crustacea, mollusca, insekta, fungi dan diperkirakan kelimpahannya paling banyak nomor dua setelah selulosa (Lim, 2002 ; Gylienè et al., 2003 ; Kim, 2004 ; Fouda, 2005 ; Shanmugasundaram, 2006). Disamping itu, pemanfaatan kitosan merupakan suatu upaya meningkatkan nilai tambah produk hasil perairan seperti udang dan kepiting sekaligus mengatasi masalah karena udang dan kepiting menghasilkan limbah berupa kulit/cangkang yang selama ini kurang termanfaatkan (Yamazaki, 2007).

Kitosan merupakan biopolimer yang diperoleh dari deasetilasi kitin. Kitosan terdiri dari poli (2-deoksi-2asetilamin-2-glukosa) dan poli (2-deoksi2-aminoglukosa) yang berikatan secara (1-4) $\beta$-glikosidik, struktur kitosan tersaji pada Gambar 1 (Tolaimatea et al., 2003)

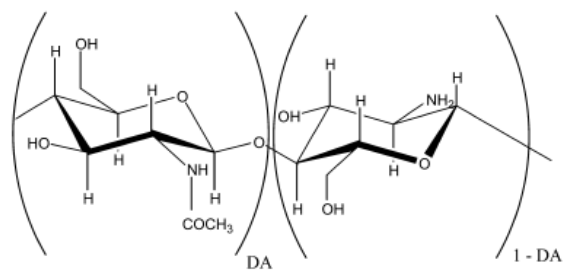

Gambar 1 Struktur kitosan (DA adalah derajat deasetilasi)
Penggerak utama pengembangan aplikasi-aplikasi baru kitosan adalah peranannya sebagai polimer kationik yang secara ekonomis dapat diproses secara alami dari kitin yang melimpah, tetapi tidak beracun, dapat didaur ulang dan ramah lingkungan (Rege dan Lawrence, 1999). Akhir-akhir ini kitosan banyak dimanfaatkan dalam beragam industri.

Kitosan merupakan polimer kationik yang bersifat nontoksik, dapat mengalami biodegradasi dan bersifat biokompatibel. Kitosan juga memiliki kegunaan yang sangat luas dalam kehidupan sehari-hari misalnya sebagai adsorben limbah logam berat dan zat warna, pengawet, antijamur, kosmetik, farmasi, flokulan, antikanker, dan antibakteri. Kitosan dapat aktif dan berinteraksi dengan sel, enzim atau matrik polimer yang bermuatan negatif (Stephen, 1995) serta sebagai bahan antibakteri (Lim et al., 2002; No et al., 2002).

Menurut Fernández et al. (2006) kitosan memberikan aktivitas antibakteri (E. coli, S. aureus, Pseudomona aeruginosa dan Salmonella paratyphi B). Kemampuan kitosan mengkoagulasi dan membentuk komplek dengan DNA, 
menyebabkan mekanisme antara sel dan gugus kationik pada polimer kitosan masih perlu dikaji lebih lanjut (Dunn et al., 1992).

Performance sifat-sifat kitosan sangat dipengaruhi oleh dua parameter penting yaitu: derajat deasetilasi (DD) dan berat molekul (BM). Besarnya DD dan BM ini sangat dipengaruhi oleh konsentrasi basa, temperatur, waktu dan pengulangan proses selama pembentukan kitosan.

Pada penelitian ini mengkaji aktivitas antibakteri kitosan terhadap bakteri $S$. aureus.

\section{METODE PENELITIAN \\ Bahan dan Alat}

Bahan yang digunakan adalah: kulit udang putih, $\mathrm{HCl}, \mathrm{NaOH}, \mathrm{NaOCl}$, kultur murni bakteri $S$. aureus ATCC 25293, nutrisi cair (NB), nutrisi padat (NA), akuades dan akuabides.

Peralatan yang digunakan meliputi: mortar, blender, ayakan 100 mesh, seperangkat alat refluks, oven, timbangan analitik Mettler AE200, kurs porselin, spritus, vortex, autoklaf, ose, cawan petri, pipet mikro $1 \mathrm{~mL}$, pipet ukur, dan inkubator.

\section{Cara Kerja}

Kulit udang yang lolos 100 mesh direaksikan dengan $\mathrm{NaOH}$ untuk deproteinase, demineralisasi dengan $\mathrm{HCl}$, pemutihan menggunakan $\mathrm{NaOCl}$ dan deasetilasi sebanyak tiga kali menggunakan $\mathrm{NaOH}$. Kitosan hasil sintesis ditentukan derajat dan berat molekulnya.

Uji antibakteri terlebih dahulu dilakukan pada larutan asam asetat, sebagai kontrol aktivitas antibakteri larutan kitosan. Mengacu pada Liu et al. (2006), kondisi uji dibuat dua set yaitu uji dengan asam asetat dan tanpa asam asetat (hanya NB) sebagai kontrol. Tujuh variasi konsentrasi asam asetat $(50,100$, 150, 200, 250, 300 dan 350 ppm) dibuat.
Setiap konsentrasi asam asetat dibuat 25 $\mathrm{mL}$ dengan $15 \mathrm{~mL} \mathrm{NB}$ dan $5 \mathrm{~mL}$ kultur bakteri $S$. aureus $10^{8} \mathrm{CFU} / \mathrm{mL}$. Efek asam asetat terhadap pertumbuhan $S$. aureus pada jam ke-0, 24 dan 48 dimonitor dengan spektrofotometer UVVis dengan panjang gelombang 460nm dan diukur $\mathrm{CFU} / \mathrm{mL}$ dari bakteri yang masih hidup dengan platting technique. Kontrol pertumbuhan bakteri $S$. aureus dalam media NB juga dihitung.

Sampel kitosan dilarutkan dalam asam asetat dengan variasi konsentrasi $[1,4 ; 1,0 ; 0,6 ; 0,4 ; 0,2 ; 0,1$ dan $0,05 \%$ (b/v)]. Sampel-sampel kitosan termasuk asam asetat sebanyak $25 \mathrm{~mL}$ ditambah kultur bakteri $S$. aureus $10^{8} \mathrm{CFU} / \mathrm{mL}$ masing-masing $5 \mathrm{~mL}$. Campuran kemudian diinkubasi pada $37{ }^{\circ} \mathrm{C}$. Efek konsentrasi kitosan terhadap pertumbuhan $S$. aureus pada jam ke-0, 24 dan 48 dimonitor dengan spektrofotometer UV-Vis dengan panjang gelombang 460nm dan diukur CFU/mL dari bakteri yang masih hidup dengan platting technique. Sebagai kontrol media digunakan pertumbuhan bakteri $S$. aureus dalam media NB yang juga dihitung dengan cara yang sama. Semua dilakukan secara duplo.

\section{HASIL DAN PEMBAHASAN}

Kitosan yang dihasilkan dari isolasi serbuk kulit udang berwarna coklat muda seberat $15,69 \%$ dari berat serbuk udang yang digunakan. Perhitungan derajat deasetilasi dengan spektra IR dapat menggunakan metode baseline $a$ dan $b$ yang diusulkan oleh Baxter pada Khan (2002). Berdasarkan hasil perhitungan diperoleh derajat deasetilasi kitosan hasil sintesis adalah 87,50 untuk metode baseline $a$ dan 96,50 untuk metode baseline $b$. Nilai baseline $b$ lebih tinggi daripada baseline $a$, hal ini serupa dengan yang uraikan oleh Khan (2002). Semakin tinggi derajat deasetilasi maka semakin banyak jumlah gugus amina pada kitosan, sehingga jumlah gugus amina yang 
terprotonasi dalam kondisi asam juga meningkat dan akhirnya dapat larut sempurna, selain itu akan meningkatkan peluang kitosan berinteraksi dengan muatan negatif pada dinding sel mikroorganisme.

Viskosimetri merupakan metode paling mudah dan cepat untuk menentukan berat molekul (Dunn et al., 1992). Dari hasil perhitungan diperoleh berat molekul kitosan hasil isolasi sebesar 176634,4 Da untuk derajat deasetilasi hasil perhitungan dengan baseline $a$ dan 129177,0 Da untuk derajat deasetilasi hasil perhitungan dengan baseline $b$. Berat molekul sangat berkaitan dengan kelarutan kitosan dalam asam asetat,

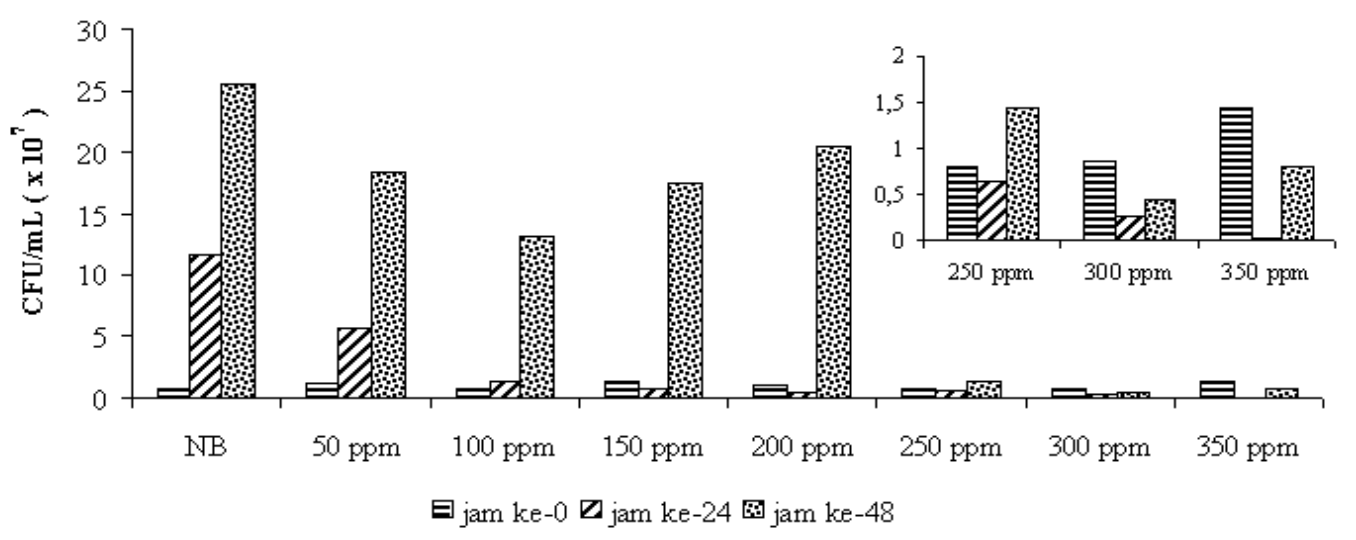

Gambar 3 Pertumbuhan bakteri S. aureus pada larutan asam asetat (Inset: pertumbuhan bakteri pada larutan asam asetat $250 \mathrm{ppm}, 300 \mathrm{ppm}$ dan 350 ppm, skala 0-2.10 $\mathrm{CFU} / \mathrm{mL}$ )

Berdasarkan hasil yang diperoleh dapat disimpulkan semakin besar konsentrasi asam asetat maka semakin besar aktivitas antibakteri. Berdasarkan hasil tersebut sebaiknya untuk memanfaatkan kitosan dalam uji bakteri digunakan pelarut asam asetat dengan konsentrasi kurang dari 100 ppm. kelarutan akan turun ketika berat molekul besar.

Menurut Liu et al. (2006) asam asetat memiliki aktivitas antibakteri. Oleh karena itu, ketika digunakan sebagai pelarut kitosan maka peran serta asam asetat tidak dapat diabaikan. Dalam penelitian ini dikaji pengaruh konsentrasi asam asetat terhadap pertumbuhan bakteri $S$. aureus dengan hasil yang diperoleh disajikan dalam Gambar 3. 


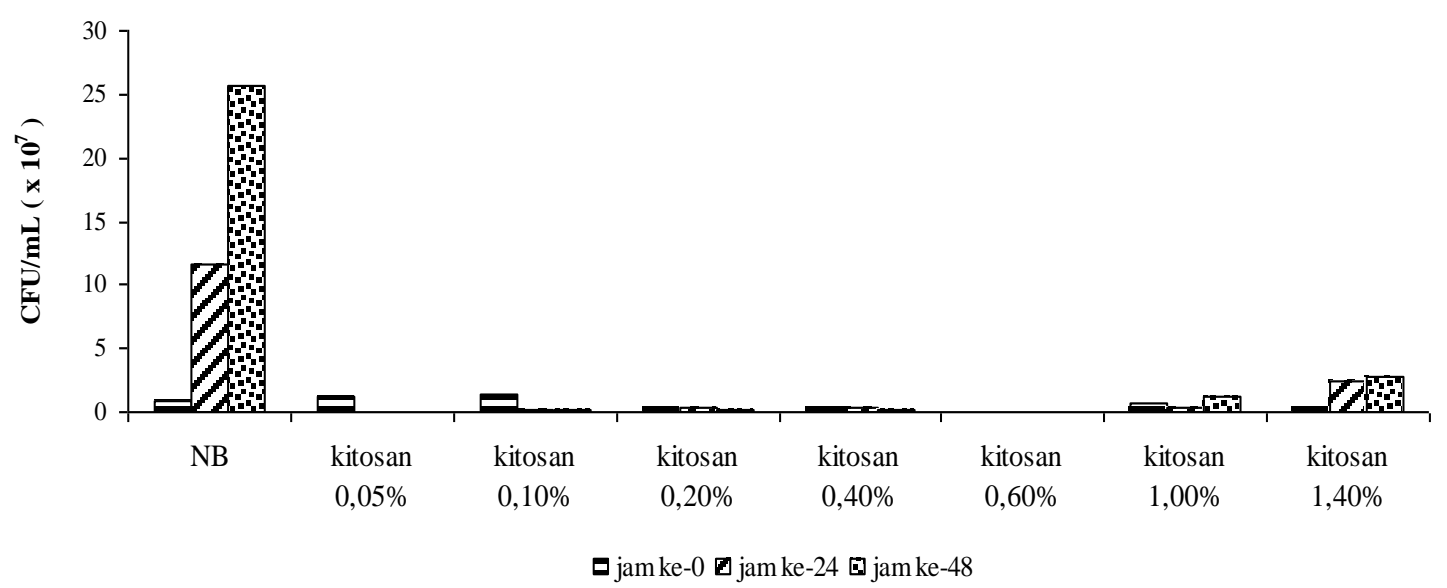

(a)

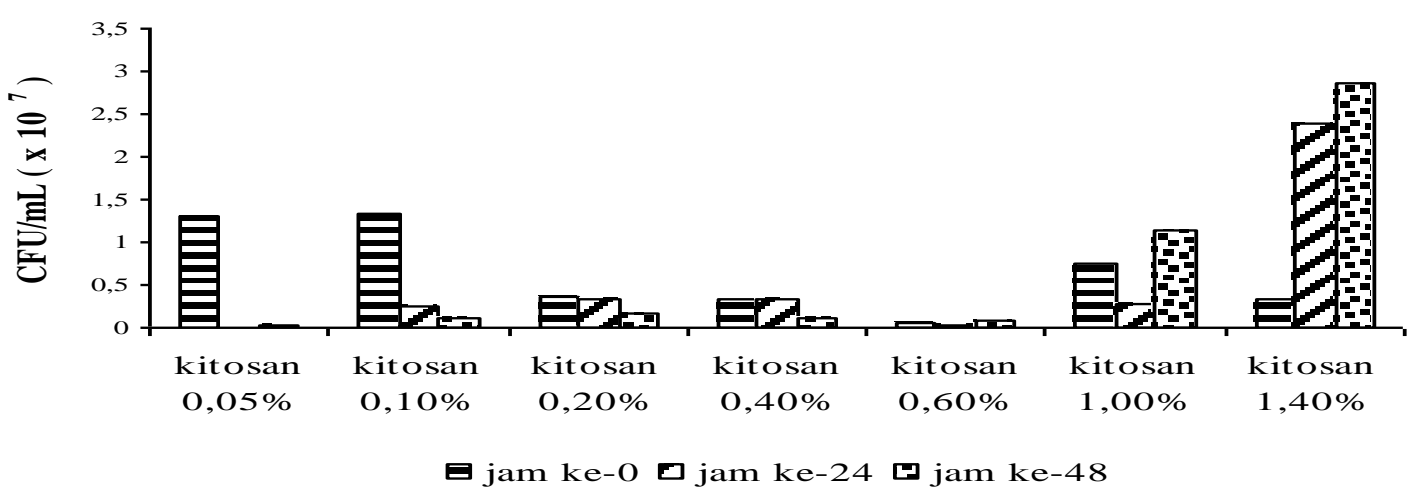

(b)

Gambar 2 Pertumbuhan bakteri S. aureus pada (a). Variasi larutan kitosan dan kontrol media NB, (b) variasi larutan kitosan

Beberapa mekanisme penghambatan mikroba oleh kitosan telah diusulkan beberapa peneliti, tetapi mekanisme yang pasti sampai saat ini belum diketahui. Mekanisme yang paling banyak diterima adalah interaksi muatan positif kitosan dengan muatan negatif pada permukaan bakteri, yang menyebabkan perubahan permeabilitas permukaan sel. Hal ini akan menyebabkan hilangnya beberapa penyusun sel seperti protein, asam amino dan glukosa. Alhasil kitosan akan menghambat metabolisme mikroorganisme dan akhirnya mengakibatkan kematian sel. Kemungkinan mekanisme yang lain adalah muatan positif kitosan berinteraksi dengan DNA bakteri, yang mengakibatkan terhambatnya sintesis RNA dan protein. Pada mekanisme ini, kitosan harus mempunyai berat molekul kecil agar dapat masuk dalam sel mikroorganisme.

\section{KESIMPULAN}

Berdasarkan hasil penelitian diperoleh semakin kecil konsentrasi kitosan akan memberikan aktivitas antibakteri terhadap bakteri $S$. aureus yang semakin besar. 


\section{DAFTAR PUSTAKA}

Dunn, E. T.; Li, Q.; Grandmaison, E. W. dan Goosen, M. F. A, 1992, Applications and Properties of Chitosan, J. Bioact. Compat. Polym., 7, 370.

Fernández, M.; Plessing, C.V. dan Cárdenas, G., 2006, Preparation and characterization of chitosan gels, J. Chil. Chi. Soc., 51, 10221024.

Fouda, M. M. G., (2005), Use of Natural Polysaccharides in Medical Textile Applications, (disertasi) Fachbereich Chemie Universitat Duisburg-Essen, Germany.

Gyliene, O., Inga R., Rima, T. and Ona, N., (2003), Chemical Composition and Sorption Properties of Chitosan Produced from Fly Larva Shells, Chemija (Vilnius), 14(3), 121-127.

Khan, T.A.; Peh, K.K. dan Ch'ng H.S, 2002, Reporting degree of deacetylation values of chitosan: the influence of analytical methods, J Pharm Pharmaceut Sci, 5(3):205-212.

Kim S. F., (2004), Physicochemical and Functional Properties of Crawfish Chitosan as Affected by Different Processing Protocols, (tesis) Departement of Food Science Louisiana State University.

Lim, S., 2002. Synthesis of a fiberreactive chitosan derivative and its application to cotton fabric as an antimicrobial finish and a dyeing-improving agent, (Dissertation) Fiber and polymer science, North Carolina State University.
Liu N., Xi-Guang, C., Hyun-Jin P., ChenGuang, L., Cheng-Sheng, L, Xiang-Hong, M. and Le-Jun, Y.,(2006), Effect of MW and Concentration of Chitosan On Antibacterial Activity of Escherichia coli, Carbohydr. Polym., 64, 60-65.

No, H. K.; Park, N.Y; Lee, S.H. dan Meyers, S. P., 2002, Antibacterial activity of chitosans and chitosan oligomers with different molecular weights, Int. J. Food Microbiol. ,74, 65- 72.

Rege, P. R. dan Lawrence H. B., 1999, Chitosan processing: influence of process parameters during acidic and alkaline hydrolysis and effect of the processing sequence on the resultant chitosan's properties, Carbohydr. Res., 321, 235-245.

Tolaimatea, A.; Desbrieresb, J.; Rhazia, M., dan Alaguic, A., 2003, Contribution to the preparation of chitins and chitosans with controlled physico-chemical properties, Polym. J. , 44, 79397952.

Shanmugasundaram, O. L., (2006) Chitosan Coated Cotton Yarn and It's effect Antimicrobial Activity, JTATM, 5(3), 1-6.

Yamazaki, M., (2007), Chemical Modification of Chitosan Films for Improved Hemostatic and Bioadhesive Properties, (disertasi), Fiber and Polymer Science Program, College of Textiles, North Carolina State University. 